Original Article

\title{
Effects of Solanum lycopersicum L. (tomato) against isoniazid and rifampicin induced hepatotoxicity in wistar albino rats
}

\author{
Efeitos de Solanum lycopersicum L. (tomate) contra hepatotoxicidade induzida por \\ isoniazida e rifampicina em ratos albinos wistar
}

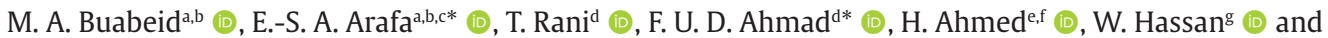 \\ G. Murtazag ${ }^{\circ}$ \\ ajman University, College of Pharmacy and Health Sciences, Department of Clinical Sciences, Ajman, United Arab Emirates \\ ${ }^{\mathrm{b}}$ Ajman University, Centre of Medical and Bio Allied Health Sciences Research, Ajman, United Arab Emirates \\ 'Beni-Suef University, Faculty of Pharmacy, Department of Pharmacology and Toxicology, Beni-Suef, Egypt \\ d The Islamia University of Bahawalpur, Faculty of Pharmacy, Department of Pharmacology, Bahawalpur, Pakistan \\ eImran Idrees College of Pharmacy, Sialkot, Pakistan \\ f Sialkot Medical College, Department of Pharmacology, Sialkot, Pakistan \\ gCOMSATS University Islamabad, Department of Pharmacy, Lahore, Pakistan
}

\begin{abstract}
Anti-tuberculosis drugs are reported to cause hepatotoxicity, which varies from asymptomatic rise of the hepatic enzymes. Hepatoprotective plants plays important role to protect liver. This study investigated the hepatoprotective potential of the Solanum lycopersicum in rats intoxicated with Isoniazid and Rifampicin (INH+RIF) to induce hepatotoxicity. Thirty wistar albino rats were divided into five groups of six animals each. Group 1 rats were kept control while groups II, III, IV and V were administered with INH+RIF $(75+150 \mathrm{mg} / \mathrm{kg}$ ) orally, for seven consecutive days. For treatment, rats in group III received silymarin while animals in group IV and V were provided with $40 \mathrm{mg} / \mathrm{kg}$ and $80 \mathrm{mg} / \mathrm{kg}$ of Solanum lycopersicum extract, respectively. On day 0 and $8^{\text {th }}$ blood samples were collected for the analysis of hepatic biomarkers. The data were subjected to one-way ANOVA and Bonferroni's post hoc test for statistical analysis. Hepatotoxicity induced by INH+RIF resulted in significant elevation of serum hepatic enzymes including Aspartate aminotransferase (AST), Alanine aminotransferase (ALT), Alkaline phosphatase (ALP), and total bilirubin while decreased the albumin level. The Solanum lycopersicum at dose of $80 \mathrm{mg} / \mathrm{kg}$ significantly reduced the hepatic enzymes AST, ALT, ALP and bilirubin while the albumin level was significantly increased. The treatment had non-significant effect on body and liver weight. Drug induced hepatotoxicity can be effectively treated with Solanum lycopersicum at $80 \mathrm{mg} / \mathrm{kg}$ dose.
\end{abstract}

Keywords: isoniazid and rifampicin, hepatotoxicty, silymarin, Solanum lycopersicum, antioxidant.

\begin{abstract}
Resumo
As drogas antituberculose são relatadas como causadoras de hepatotoxicidade, ocasionando o aumento assintomático das enzimas hepáticas. As plantas hepatoprotetoras desempenham um papel importante na proteção do fígado. Este estudo investigou o potencial hepatoprotetor de Solanum lycopersicum em ratos que foram intoxicados com isoniazida e rifampicina (INH + RIF) para induzir hepatotoxicidade. Trinta ratos wistar albinos foram divididos em cinco grupos de seis animais cada. Os ratos do grupo 1 representaram o grupo controle, enquanto os ratos dos grupos II, III, IV e V receberam INH + RIF $(75+150 \mathrm{mg} / \mathrm{kg})$ por via oral, por sete dias consecutivos. Para o tratamento, os ratos do grupo III receberam silimarina, enquanto os animais do grupo IV e V receberam $40 \mathrm{mg} / \mathrm{kg}$ e $80 \mathrm{mg} / \mathrm{kg}$ de extrato de $S$. lycopersicum, respectivamente. Nos dias 0 e 8 , foram coletadas amostras de sangue para análise de biomarcadores hepáticos. Os dados foram submetidos a teste unilateral (ANOVA) e post hoc de Bonferroni para análise estatística. A hepatotoxicidade induzida por INH + RIF resultou em elevação significativa das enzimas hepáticas séricas, incluindo aspartato aminotransferase (AST), alanina aminotransferase (ALT), fosfatase alcalina (ALP) e bilirrubina total, enquanto houve a diminuição do nível de albumina. O S. lycopersicum, na dose de $80 \mathrm{mg} / \mathrm{kg}$, reduziu significativamente as enzimas hepáticas AST, ALT, ALP e bilirrubina, enquanto o nível de albumina aumentou de forma significativa. $O$ tratamento não teve efeito significativo no peso corporal e hepático. A hepatotoxicidade induzida por drogas pode ser tratada de forma eficaz com S. lycopersicum na dose de $80 \mathrm{mg} / \mathrm{kg}$.
\end{abstract}

Palavras-chave: isoniazida e rifampicina, hepatotoxicidade, silimarina, Solanum lycopersicum, antioxidante.

*e-mail: e.arafa@ajman.ac.ae; fazi2353@yahoo.com

Received: July 23, 2021 - Accepted: October 23, 2021 


\section{Introduction}

The liver is a heterogeneous organ and is considered next to the brain for its complexity in structure and function. It is the largest gland, most versatile, reddish brown in color and is triangular in shape (Feng et al., 2016). It performs several important functions in adult vertebrates'. The liver detoxifies drugs, hormones, and other biologically active molecules either by their excretion through bile or by phagocytosis through kupffer cells lining the sinusoids. Some other compounds are chemically altered within the liver cells. Similarly certain drugs (penicillin, macrolides and sulfonamides) and steroidal hormones (aldosterone, estrogen, and cortisol) are inactivated through chemical modification (Knolle and Wohlleber, 2016). Liver enzymes convert these hormones molecules and drugs into polar form either by conjugation or hydroxylation. The derivatives thus produced are water soluble and are excreted in the urine (Pittol et al., 2020).

Anti-tuberculosis drugs induced hepatotoxicity is noted in $5-28 \%$ of patients (Ostapowicz et al., 2002). About $20 \%$ of the patients, who take the isoniazid either in combination or single form, develop elevation in liver enzymes. Hepatotoxicity induced by anti-TB drug may changes from the asymptomatic elevations of liver enzymes to hepatic failure (Tostmann et al., 2008). Fulminant liver failure, induced by anti-TB drug when compared with the acute viral hepatitis, which appears to have worse outcome, with a death rate between 0.042 and 0.07 per 1000 patients during therapy (Ostapowicz et al., 2002). Isoniazid ( $\mathrm{INH}$ ) can easily penetrate into the macrophages and works to control both intracellular and extracellular pathogens (Matt et al., 2017). The most serious adverse effect of isoniazid is hepatitis. The incidence of damage increases when INH is taken with rifampicin, or by the patients of age greater than 35 years and in persons who take alcohol daily. Hepatocellular pattern of drug induced liver injury is associated with Rifampicin (Trousil et al., 2017). The liver toxicity of other anti-tuberculosis drugs is increased by Rifampicin. Rifampicin activates the xeno sensing pregnane $X$ receptor (PXR), whichis a member of the nuclear receptor, superfamily of ligand-dependent transcription factors. In the activated promotors, PXR binds to response elements and also up regulates transcription of phase I and II enzymes that are involved in drug metabolism like glutathione S-transferases (GSTs), cytochrome P450 (CYP)s and transporters that are involved in phase III. Many metabolic enzyme pathways are induced by rifampicin via the hepatocyte PXR in particular cytochrome P450 (CYP3A4) system (Ramachandran et al., 2018).

Solanum lycopersicum (S. lycopersicum) commonly known as tomato, in the red-ripe and fresh form, lycopene is present as cis- (9-21\%) and all-trans (79-91\%) isomers (Abdel-Fattah \& Al-Amri, 2012). It contains different types of phytochemicals such aslycopene that is a carotenoids (highest concentration -85\%), phytofluene, phytoene, carotenoid $\beta$-carotenoid, the provitamin A, polyphenols including kaempferol, naringenin quercetin. Nutrients such as folate, vit-C, vit-K, vit-E, vit-B, calcium, phosphorus, sulphur, potassium and iron are present in tomato. Sugars like ketoses, aldoses, disaccharides, polysaccharides mainly starch, amino acids, proteins and enzyme polyphenol oxidase, phytosterol like cholesterol, sitosterol and small quantities of fats are also present. All of these are known to participate significantly towards the antioxidant activity of tomato (Chaudhary et al., 2018; Piri et al., 2020).

S. lycopersicum has long folkloric medicinal use and it was considered for use in several ailment like antiinflamatory, diuretic, and antibiotic. Owing to its phytochemical composition this plant has the potential to be used in the treatment of several diseases (Aminuddin and Suraiya, 2018).

S. lycopersicum have hepatoprotective effect due to its antioxidant properties. Whereas isoniazid and rifampicin are well recognized to cause the hepatotoxicity. In this study we hypothesize that $S$. lycopersicum being a strong anti-oxidant and free-radical scavenger, protects the liver against hepatotoxicity induced by isoniazid and rifampicin.

\section{Materials and Methods}

\subsection{Materials}

Isoniazid and Rifampicin (Rimactal INH, Global Pharmaceuticals), Silymarin (Silliver, Abbott Laborteries), formalin, Xylazine (prix pharmaceutical Lahore), Ketamine (Indus pharma Lahore), aqueous ethanol and ether, were procured from the local market.

\subsection{Animals}

Experiments were performed according to the guidelines of Institutional Animal Ethics Committee, The Islamia University of Bahawalpur. Wistar albino rats having 120-200 g weight were housed at animal house, Faculty of pharmacy and alternative medicine, The Islamia University of Bahawalpur. The thirty (30) wistar albino rats were kept in polycarbonate cages that were covered with saw dust (changed after every $48 \mathrm{hr}$ ) under standard lab conditions. Rats were provided with standard diet pellets and water ad libitum. Female wistar albino rats were acclimatized to a regimen of 12 hrs dark and 12 hrs light. According to the study animals were divided into five groups.

\subsection{Preparation of crude extract}

Fresh S. lycopersicum were purchased from local market and stored in the refrigerator for use in the experiments. Fresh ripe tomato fruits of $500 \mathrm{~g}$ were, washed, and separated from their seeds. The pulp was dried in sunlight for a week. It was ensured that the sunlight could not harm the phytoconstiuent of the pulp. After that it was ground to make homogenized powder using blender and stored in closed container until used (Wang et al., 2019a). The dose of tomato powder at rate of 40 and $80 \mathrm{mg} / \mathrm{kg}$ was calculated on the basis of weight for each animal belonging to respective groups. Extract was prepared by following the method described previously (Faridi Esfanjani et al., 2017). The calculated dose was then dissolved in $1.5 \mathrm{ml}$ of distilled water and administered per oral to each animal of treatment groups one hour before induction of hepatic 
intoxication. Provision of treatment as per mentioned dosage was continued for seven days.

\subsection{Phytochemical screening}

Phytochemical screening was carried out to identify the possible phytoconstiuents present in the crude extract by following the standard methods (Wang et al., 2019) \#29).

\section{2..5. Induction of hepatotoxocity}

$\mathrm{INH}+\mathrm{RIF}(75+150 \mathrm{mg} / \mathrm{kg})$ were dissolved in $1.5 \mathrm{ml}$ distilled water after calculation of the required dose and were drenched to rats individually once a day for a period of seven days for inducing hepatotoxicity (Combrink et al., 2020).

\subsection{Experimental protocol}

The rats were randomly divided into five groups of six animals each. Rats in experimental groups were provided liver intoxication and treatment as given in Table 1.

\subsection{Blood samples collection}

At day 0 and 8 the animals were anesthetized with $0.2 \mathrm{~mL} / 100 \mathrm{mg}$ ketamine at the rate of $50 \mathrm{mg} / \mathrm{kg}$ and xylazine $5 \mathrm{mg} / \mathrm{kg}$ body weight in 10:1 combination, respectively. Using retro-orbital method, $2 \mathrm{ml}$ blood sample per animal was drawn with the help of capillary tube. Blood after collection was allowed to clot for 20 minutes. Thereafter serum was separated through centrifugation at rate of $40000 \mathrm{rpm}$ for 15 minutes. The serum samples thus obtained were freezed and stored in the refrigerator, using already labelled eppendorf tubes.

\subsection{Biochemical analysis for assessment of liver function}

Serum collected was used for various liver assays to determine aspartate aminotransferase (AST), alanine aminotransferase (ALT), alkaline phosphatase (ALP), total bilirubin. The colorimetric method as described for bilirubin (Tan et al., 2020), as well as, ALT and AST and ALP, were measured by the biochemistry analyzer.

\subsection{Statistical analysis}

The obtained data were showed as mean \pm Standard Error of the Mean (SEM). The data were subjected to

Table 1. Showing the study design and treatment group.

\begin{tabular}{|c|c|c|c|}
\hline $\begin{array}{l}\text { Group } \\
\text { No. }\end{array}$ & $\begin{array}{l}\text { No. of } \\
\text { animals }\end{array}$ & $\begin{array}{c}\text { Intoxication and } \\
\text { dosage }\end{array}$ & Treatment and dosage \\
\hline 1 & 6 & Normal saline (1.5 ml) & - \\
\hline 2 & 6 & $\begin{array}{l}\text { INH+RIF } 75+150 \mathrm{mg} / \mathrm{kg} \\
(1.5 \mathrm{ml} \text { in DW/animal) }\end{array}$ & - \\
\hline 3 & 6 & $\begin{array}{l}\mathrm{INH}+\mathrm{RIF} 75+150 \mathrm{mg} / \mathrm{kg} \\
(1.5 \mathrm{ml} \text { in DW/animal) }\end{array}$ & $\begin{array}{l}\text { Silymarin } 200 \mathrm{mg} / \mathrm{kg} \\
(1.5 \mathrm{ml} \text { in DW/animal) }\end{array}$ \\
\hline 4 & 6 & $\begin{array}{l}\mathrm{INH}+\mathrm{RIF} 75+150 \mathrm{mg} / \mathrm{kg} \\
(1.5 \mathrm{ml} \text { in DW/animal) }\end{array}$ & $\begin{array}{l}\text { gS. lycopersicum } 40 \mathrm{mg} / \mathrm{kg} \\
\text { (1.5 ml in DW/animal) }\end{array}$ \\
\hline 5 & 6 & $\begin{array}{l}\text { INH+ RIF } 75+150 \mathrm{mg} / \mathrm{kg} \\
(1.5 \mathrm{ml} \text { in DW/animal) }\end{array}$ & $\begin{array}{c}\text { g S. lycopersicum } 80 \mathrm{mg} / \mathrm{kg} \\
(1.5 \mathrm{ml} \text { in DW/animal) }\end{array}$ \\
\hline
\end{tabular}

one-way ANOVA (analysis of variance) and Bonferroni's post hoc test for statistical analysis of the experimental groups. If $p$-value $<0.05$, then it was taken as statistically significant. For statistical analysis GraphPad PRISM software, version 5.01 was used.

\section{Results}

\subsection{Phytochemical screening of S.lycopersicum extract}

Preliminary phytochemical analysis revealed a visible lack of tannins, saponnins, glycosides, proteins and amino acids, terpenoids and quinones in S. lycopersicum extract, and a notable presence of bioactive compounds along with other secondary metabolites such as alkaloids, carbohydrates, flavonoids, phenols as given in Table 2.

\subsection{Effect of Solanum lycopersicum treatment on serum total bilirubin (STB)}

The STB level was found similar $(\mathrm{P}>0.05)$ for the rats of all groups on day 0 of the experiment. On day 8, STB level of rats in all groups was increased when compared to those of control group $(0.25 \pm 0.051 \mathrm{mg} / \mathrm{dl})$. Rats treated with silymarin, which is a proven hepatoprotective drug and used as standard in this study, group III showed non-significant $(\mathrm{P}>0.05)$ rise in STB. The increase in STB level was significant $(\mathrm{P}<0.05)$ in hepatotoxic group $(0.96 \pm 0.067 \mathrm{mg} / \mathrm{dl})$ and $S$. lycopersicum-treated group $(0.52 \pm 0.042 \mathrm{mg} / \mathrm{dl})$. This indicated that INH+RIF have induced toxicity in rat of group II, which is shown by the rise in STB. The STB level of group IV $(0.52 \pm 0.042 \mathrm{mg} / \mathrm{dl})$ was significantly high as compared to silymarin treated group III but showed a declining trend as compared to the group II. This shows that S. lycopersicum can repair the INH+RIF induced hepatotoxicity but the dose used for this group was not sufficient to cater the toxic effect. However, in Group V $(0.47 \pm 0.040 \mathrm{mg} / \mathrm{dl})$ the STB level was $(\mathrm{P}>0.05)$ lowered as compared to hepatotoxic group II and statistically similar to group III, which shows the repairing response of hepatotoxicity with the high dose of S. lycopersicum (Figure 1A).

Table 2. Phytochemical analysis of extract of S. lycopercsicum. The +sign indicates presence and - sign indicates the absence of phytoconstituents.

\begin{tabular}{cc}
\hline Carbohydrates & + \\
\hline Alkaloids & ++++ \\
Glucosides & - \\
Flavonoids & ++ \\
Phenols & + \\
Protein and amino acids & - \\
Tannins & - \\
Saponins & - \\
Terpenoids & - \\
Quinones & - \\
\hline
\end{tabular}



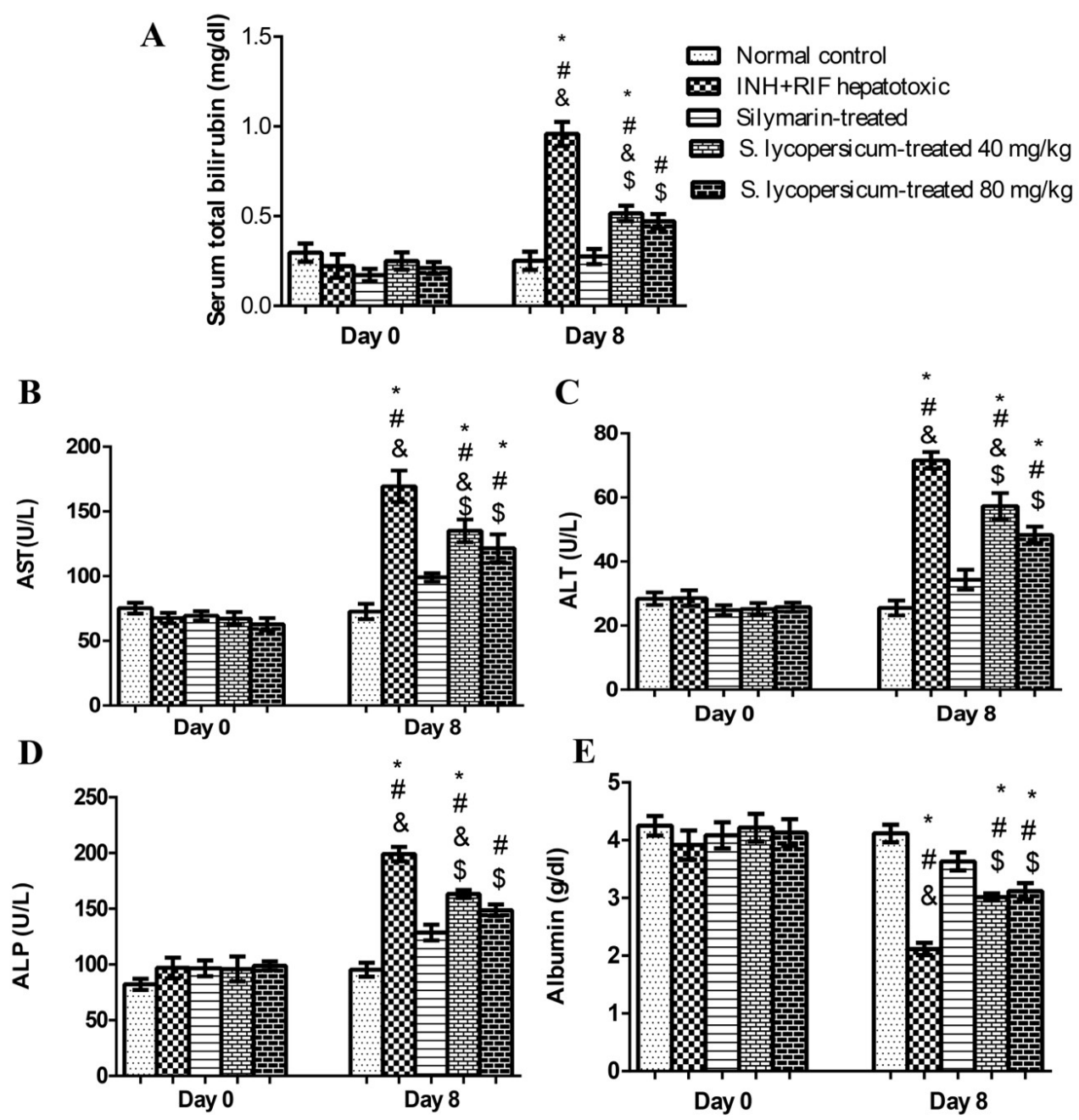

Figure 1. (A) Serum total bilirubin; (B) Serum aspartate aminotransferase (AST); (C) Serum alanine aminotransferase (ALT); (D) Alkaline phosphatases and; (E) Serum albumin of control, INH+RIF hepatotoxic, silymarin-treated, S. lycopersicum-treated $40 \mathrm{mg} / \mathrm{kg}$ and S. lycopersicum-treated $80 \mathrm{mg} / \mathrm{kg}$ at day 0 and day 8 . Values are presented as mean \pm Standard error of means (SEM) ( $\mathrm{n}=6$ ). The results

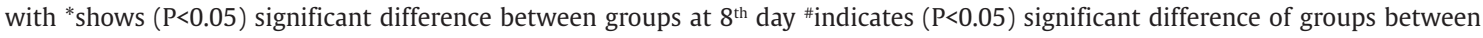
day 0 and $8^{\text {th }}$ day, ${ }^{*}$ indicates $(\mathrm{p}<0.05)$ significant difference of INH+RIF hepatotoxic and S.lycopersicum-treated groups compared with silymarin-treated group at $8^{\text {th }}$ day and sindicates $(\mathrm{p}<0.05)$ significant difference between INH+RIF hepatotoxic and S. lycopersicum-treated groups at $8^{\text {th }}$ day.

\subsection{Effect of Solanum lycopersicum on serum aspartate aminotransferase (AST)}

The AST level was found similar ( $p>0.05$ ) for the rats of all groups on day 0 of the experiment. On day 8, AST level of rats in all groups was increased when compared to those of control group. Rats treated with silymarin, group III, showed $(p>0.05)$ non-significant rise in AST. The increase in AST level was significant $(p<0.05)$ in hepatotoxic group II and S. lycopersicum-treated group IV. This indicated that INH+RIF have induced toxicity in rat of group II, which is shown by the rise in AST. The AST level of group IV was significantly higher as compared to silymarin treated group III but showed a declining trend as compared to the group II. This shows that S. lycopersicum can repair the INH+RIF induced hepatotoxicity but the dose used for this group was not sufficient to cater the toxic effect. However, in Group V the AST level was $(\mathrm{P}>0.05)$ lowered as compared to hepatotoxic group II and statistically similar to group III, which shows the repairing response of hepatotoxicity with the high dose of S. lycopersicum (Figure 1B).

\subsection{Effect of Solanum lycopersicum on serum alanine aminotransferase (ALT)}

The ALT level was found similar ( $p>0.05$ ) for the rats of all groups on day 0 of the experiment. On day $8^{\text {th }}$, ALT level of rats in all groups was increased when compared to those of control group I. Rats treated with silymarin, group III, showed $(p>0.05)$ non-significant rise in ALT. The increase in ALT level was significant $(p<0.05)$ in hepatotoxic group II and S. lycopersicum-treated group IV. The ALT level of 
group IV was significantly higher as compared to silymarin treated group III but showed a declining trend as compared to the group II. This shows that $S$. lycopersicum can repair the INH+RIF induced hepatotoxicity but the dose used for this group was not sufficient to cater the toxic effect. However, in Group V the ALT level was ( $p>0.05)$ lowered as compared to hepatotoxic group II and statistically similar to group III, which shows the repairing response of hepatotoxicity with the high dose of S. lycopersicum (Figure 1C).

\subsection{Effect of Solanum lycopersium on serum alkaline phosphatases (ALP)}

The ALP level was found similar $(p>0.05)$ for the rats of all groups on day 0 of the experiment. On day 8 , ALP level of rats in all groups was increased when compared to those of control group I. Rats treated with silymarin, group III, showed $(p>0.05)$ non-significant rise in ALP. The increase in ALP level was significant $(p<0.05)$ in hepatotoxic group II and S. lycopersicum-treated group IV. This indicated that INH+RIF have induced toxicity in rat of group II, which is shown by the rise in ALP. The ALP level of group IV was significantly higher as compared to silymarin treated group III but showed a declining trend as compared to the group II. This shows that S. lycopersicum can repair the INH+RIF induced hepatotoxicity but the dose used for this group was not sufficient to cater the toxic effect. However, in Group V the ALP level was ( $p>0.05$ ) lowered as compared to hepatotoxic group II and statistically similar to group
III, which shows the repairing response of hepatotoxicity with the high dose of S.lycopersicum (Figure 1D).

\subsection{Effect of Solanum lycopersicum on serum albumin}

The albumin level was found similar $(p>0.05)$ for the rats of all groups on day 0 of the experiment. On day $8^{\text {th }}$, albumin level of rats in all groups was decreased when compared to those of normal control group I $(4.1 \pm 0.15 \mathrm{~g} / \mathrm{dl})$. Rats treated with silymarin, group III $(3.6 \pm 0.16 \mathrm{~g} / \mathrm{dl})$ showed $(p>0.05)$ non-significant decrease in albumin. The decrease in albumin level was significant $(p<0.05)$ in hepatotoxic group II $(2.1 \pm 0.10 \mathrm{~g} / \mathrm{dl})$. This indicated that INH+RIF have induced toxicity in rat of group II, which is shown by the decrease in albumin. However, in Group IV $(3.0 \pm 0.06 \mathrm{~g} / \mathrm{dl})$ and Group V $(3.1 \pm 0.14 \mathrm{~g} / \mathrm{dl})$ the albumin level was $(\mathrm{P}>0.05)$ increased as compared to hepatotoxic group II and statistically similar to group III, which shows the repairing response of hepatotoxicity with the lower $40 \mathrm{mg} / \mathrm{kg}$ as well as the higher $80 \mathrm{mg} / \mathrm{kg}$ doses of $S$. lycopersicum (Figure 1E).

\subsection{Effect of Solanum lycopersicum on body weight}

On day 0 the body weight in all groups of rats was $(p>0.05)$ similar. On day $8^{\text {th }}$, body weight of rats in

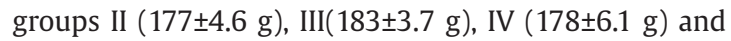
$\mathrm{V}(186 \pm 5.0 \mathrm{~g})$ was increased when compared to those of normal control group I ( $172 \pm 5.2 \mathrm{~g})$, but the increase was $(p>0.05)$ non-significant as shown in (Figure 2A).

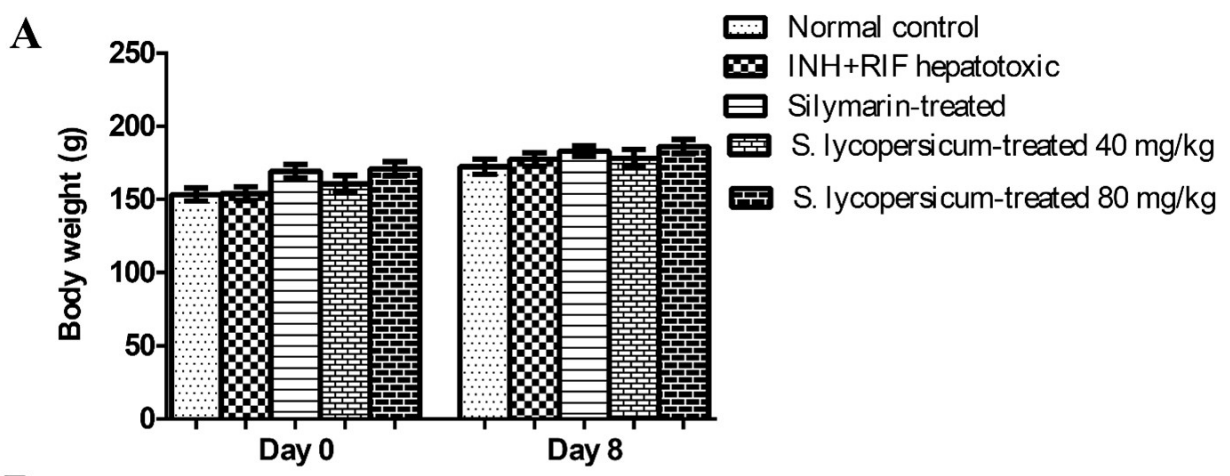

B

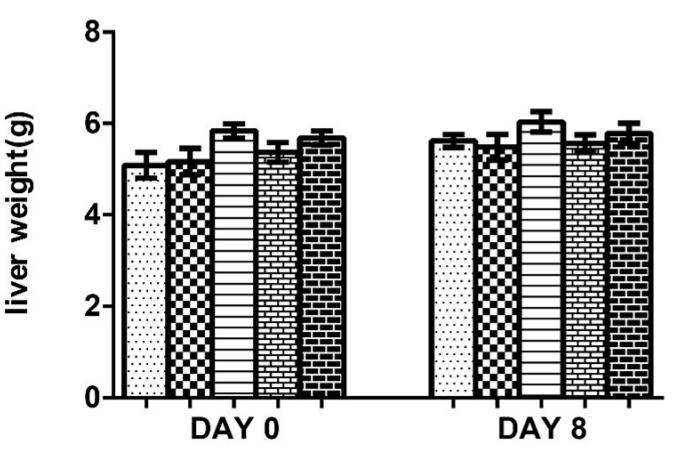

Figure 2. (A) Body weight (B) liver weight of normal control, INH+RIF hepatotoxic, silymarin-treated, S. lycopersicum-treated $40 \mathrm{mg} /$ $\mathrm{kg}$ and S. lycopersicum-treated $80 \mathrm{mg} / \mathrm{kg}$ at day 0 and day 8 . Values are presented as mean \pm Standard error of means (SEM) (n=6). 


\subsection{Effect of Solanum lycopersicum on liver weight}

On day 0 in all groups the liver weight of rats was $(p>0.05)$ similar. On day $8^{\text {th }}$, liver weight of rats in groups II $(5.5 \pm 0.28 \mathrm{~g}), \operatorname{III}(6.0 \pm 0.22 \mathrm{~g}), \mathrm{IV}(5.6 \pm 0.18 \mathrm{~g})$ and V $(5.8 \pm 0.22 \mathrm{~g})$ was increased when compared to those of normal control group I ( $5.6 \pm 0.14 \mathrm{~g}$ ), but the increase was $(p>0.05)$ non-significant as shown in (Figure 2B).

\section{Discussion}

In the cytosol, different types of enzymes are normally present that are released into the blood stream when plasma membrane of liver cell is damaged. Measuring the levels of serum marker enzymes such as serum total bilirubin, ALT, AST and ALP are powerful tool for assessment of liver function (Elsharabasy et al., 2019). Tomato has high contents of lycopene and bioflavonoids that minimize the deleterious effects of free radicals and thus ranked as hepatoprotective agents (Sheng et al., 2019). Flavonoids are antioxidants that are scavenging the ROS (reactive oxygen species), by enzymes inhibition they suppress formation of ROS or they form chelates with the trace elements which are involved in formation of free radicals (Pham et al. 2019). Flavonoids also claimed to regulate or protect the antioxidant defenses, which includes glutathione. It proposed that one or more of these mechanisms could have contributed to the hepatoprotective effect of tomato.

The STB level of rats in all groups post treatment was increased when it is compared to normal control group I. The increase in STB level was significant $(\mathrm{P}<0.05)$ in hepatotoxic group II. This indicated that INH+RIF have induced toxicity in the rats exposed to anti TB drugs, that rises the STB. INH and RIF are reported to cause liver toxicity that is noted by increased levels of AST, ALT, ALP and total bilirubin, presence of portal triaditis and liver cell necrosis (Wang et al., 2019b). In 20\% of the patients INH is reported to induce liver toxicity which is linked with inflammatory problems (Kewalramani et al., 2020).

Rats were treated with silymarin, a proven hepatoprotective drug, group III showed non-significant $(P>0.05)$ rise in STB. Silymarin administration significantly decreased the serum total bilirubin level as compared to the hepatotoxic group II. Similar to previous reports and studies, these results show that silymarin possesses protective effects towards the anti-tuberculosis drugs toxic effects (Lai et al., 2020).

The STB level of group treated with lower dose of $S$. lycopersicum was significantly higher as compared to silymarin, but showed a declining trend as compared to the group II which was treated. This shows that $S$. lycopersicum can repair the INH+RIF induced hepatotoxicity but the dose used for this group was not sufficient to cater the toxic effect. However, in Group V the STB level was $(\mathrm{P}>0.05)$ lowered as compared to hepatotoxic group II and statistically similar to group III, which shows the repairing response of hepato-toxicity with high dose of S. lycopersicum.

The lessened levels of bilirubin by tomato pulp toward their normal values is an indication of plasma membrane stabilization and repair of liver tissues that are damaged by isoniazid and rifampicin is in agreement with that levels of AST, ALT and total serum bilirubin return to normal with the liver parenchyma and regeneration of liver cells (Mangwani et al., 2020). The AST, ALT and ALP levels were increased when compared to those of normal control group. Silymarin group III treated rats showed non-significant $(\mathrm{P}>0.05)$ rise in ALT, AST and ALP. Several studies have reported the mechanism of action of silymarin as to inhibits several isoforms of CYP450 enzymes as an oxygen free radicals scavenger (Damle et al., 2019), inhibits pro-inflammatory cytokines synthesis, increases apoptosis and potentiates the liver antioxidant capacity.

The increase in AST, ALT and ALP levels were significant $(\mathrm{P}<0.05)$ in hepatotoxic group II. This indicated that INH+RIF have induced toxicity in rat of group II, which is confirmed by the rise in AST, ALT and ALP levels. Elevated levels of these three enzymes showed abnormal integrity of liver cells (Mohammadi et al., 2019), which was resulted in the intracellular enzymes released into the systemic circulation.

The AST, ALT and ALP levels of group IV were significantly higher as compared to silymarin, group III but showed a declining trend as compared to the group II. This shows that S. lycopersicum can repair the INH+RIF induced hepatotoxicity but the dose used for this group was not sufficient to cater the toxic effect. However, in Group V the AST, ALT and ALP levels $(\mathrm{P}>0.05)$ lowered as compared to hepatotoxic group II and statistically similar to group III, which shows the repairing response of hepatotoxicity with the high dose of S. lycopersicum. Similar to this study tomato extract decreased the elevated levels of ALP, AST and ALT in rats of carbon tetrachloride $\left(\mathrm{CCl}_{4}\right)$ induced hepatic toxicity (Weremfo et al., 2011). In addition, the possibility of the tomato extract to repair liver toxicity in the liver of rats during chronic liver injury treated with $\mathrm{CCl}_{4}$ was shown previously (Jeong, 1999) The daily administration of the tomato extract was also able to attenuate the acetaminophen-induced hepatotoxicity on the liver enzyme levels. Histological results also revealed no significant liver injury in groups that received tomato extract as compared to normal (Uchendu et al., 2018).

The albumin is the most generous protein circulating in the plasma and is reported as the vital protein being synthesized by the liver (Roche et al., 2008). On day 8 , albumin level of rats in all groups was decreased when compared with those of normal control group I. Silymarin group III treated rats showed non-significant $(\mathrm{P}>0.05)$ decrease in albumin. It was reported that silymarin reduced the levels of serum ALP, ALT, AST and total bilirubin .Also it elevated total protein and serum albumin levels in drugs-treated animals (Mwaheb et al., 2017).

The decrease in albumin level was significant $(\mathrm{P}<0.05)$ in hepatotoxic group II. This indicated that INH+RIF have induced toxicity in rat of group II, which is shown by the decrease in albumin. However, in Group IV and Group V the level of albumin was ( $\mathrm{P}>0.05)$ increased when compared to hepatotoxic group II and statistically similar to group III, which shows the repairing response of hepatotoxicity with the lower $40 \mathrm{mg} / \mathrm{kg}$ as well as the higher $80 \mathrm{mg} / \mathrm{kg}$ doses of S. lycopersicum.

At the end of the experiment, liver and body weight of rats in groups II, III, IV and V was increased when compared 
to those of group I, but the increase was $(\mathrm{P}>0.05)$ nonsignificant. There was non-significant decrease in either relative liver or in body weight in INH+RIF treated animals. Similar findings were reported earlier (Sharma et al., 2019). Like the present study the researchers observed that supplementation of carotenoids did not show any effect neither in body nor in relative liver weight when compared to controls group.

\section{Conclusion}

The present study concluded that INH $75 \mathrm{mg} / \mathrm{kg}$ and RIF $150 \mathrm{mg} / \mathrm{kg}$ in combination induced hepatotoxicity in rats. The $S$. lycopersicum at $40 \mathrm{mg} / \mathrm{kg}$ showed hepatoprotective effect but the response was comparatively less. However, when the dose was increased to $80 \mathrm{mg} / \mathrm{kg}$ a better hepatoprotective response was observed. Rats in the experimental groups were found with non-significant increase in body and liver weight during the study. Based on the present results we recommend further clinical trials to find the exact mechanism of action and the exact phytoconstituents accountable for its hepto-protective effects.

\section{References}

ABDEL-FATTAH, G. and AL-AMRI, S., 2012. Induced systemic resistance in tomato plants against Fusarium oxysporum f. sp. lycopersici by different kinds of compost. African Journal of Biotechnology, vol. 11, no. 61, pp. 12454-12463.

AMINUDDIN, A.I. and SURAIYA, S., 2018. Comparison of antimicrobial activity of crude extracts of Piper betle, Aloe vera, solanum lycopersicum, cinnamomum zeylanicum and cucumis sativus against acne inducing bacteria. Asian Journal of Medicine and Biomedicine, vol. 2, no. 1, pp. 55-63.

CHAUDHARY, P., SHARMA, A., SINGH, B. and NAGPAL, A.K., 2018. Bioactivities of phytochemicals present in tomato. Journal of Food Science and Technology, vol. 55, no. 8, pp. 2833-2849. http://dx.doi.org/10.1007/s13197-018-3221-z. PMid:30065393.

COMBRINK, M., LOOTS, D.T. and DU PREEZ, I., 2020. Metabolomics describes previously unknown toxicity mechanisms of isoniazid and rifampicin. Toxicology Letters, vol. 322, pp. 104-110. http:// dx.doi.org/10.1016/j.toxlet.2020.01.018. PMid:31981687.

DAMLE, M.C., TEMBHURNE, S.V. and TODKAR, S.R., 2019. Evaluation of hepatoprotective activity of hydroalcoholic extract of onion peels containing protocatechuic acid. Journal of Drug Delivery and Therapeutics, vol. 9, no. 4, pp. 82-88.

ELSHARABASY, F., METWALLY, N., MAHMOUD, A., SOLIMAN, M., YOUNESS, E. and FARRAG, A., 2019. Phytoconstituents and hepatoprotective effect of Suaeda monoica Forssk and Suaeda pruinosa Lange. Biomedical \& Pharmacology Journal, vol. 12, no. 1, pp. 117-129. http://dx.doi.org/10.13005/bpj/1620.

FARIDI ESFANJANI, A., JAFARI, S.M. and ASSADPOUR, E., 2017. Preparation of a multiple emulsion based on pectin-whey protein complex for encapsulation of saffron extract nanodroplets. Food Chemistry, vol. 221, pp. 1962-1969. http://dx.doi.org/10.1016/j. foodchem.2016.11.149. PMid:27979187.

FENG, Y.-H., HU, X.-D., ZHAI, L., LIU, J.-B., QIU, L.-Y., ZU, Y., LIANG, S., GUI, Y. and QIAN, L.X., 2016. Shear wave elastography results correlate with liver fibrosis histology and liver function reserve. World Journal of Gastroenterology, vol. 22, no. 17, pp. 4338-4344. http://dx.doi.org/10.3748/wjg.v22.i17.4338. PMid:27158202.
JEONG, H.G., 1999. Inhibition of cytochrome P450 2E1 expression by oleanolic acid: hepatoprotective effects against carbon tetrachloride-induced hepatic injury. Toxicology Letters, vol. 105, no. 3, pp. 215-222. http://dx.doi.org/10.1016/S03784274(99)00004-1. PMid:10355542.

KEWALRAMANI, M.S., LOHIT, S.V., JAISWAL, K.M., DUDHGAONKAR, S., MAHULE, S.K. and RAGHUTE, L.B., 2020. Evaluation of hepatotoxicity of anti-tuberculosis regimens: a prospective study in tribal population of Central India. Journal of Young Pharmacists, vol. 12, no. 2, pp. 153-157. http://dx.doi.org/10.5530/ jyp.2020.12.31.

KNOLLE, P.A. and WOHLLEBER, D., 2016. Immunological functions of liver sinusoidal endothelial cells. Cellular \& Molecular Immunology, vol. 13, no. 3, pp. 347-353. http://dx.doi. org/10.1038/cmi.2016.5. PMid:27041636.

LAI, N.H., SHEN, W.C., LEE, C.N., CHANG, J.C., HSU, M.C., KUO, L.N., YU, M.C. and CHEN, H.Y., 2020. Comparison of the predictive outcomes for anti-tuberculosis drug-induced hepatotoxicity by different machine learning techniques. Computer Methods and Programs in Biomedicine, vol. 188, pp. 105307. http://dx.doi. org/10.1016/j.cmpb.2019.105307. PMid:31911332.

MANGWANI, N., SINGH, P.K. and KUMAR, V., 2020. Medicinal plants: adjunct treatment to tuberculosis chemotherapy to prevent hepatic damage. Journal of Ayurveda and Integrative Medicine, vol. 11, no. 4, pp. 522-528. http://dx.doi.org/10.1016/j. jaim.2019.02.004. PMid:31679802.

MATT, U., SELCHOW, P., DAL MOLIN, M., STROMMER, S., SHARIF, O., SCHILCHER, K., ANDREONI, F., STENZINGER, A., ZINKERNAGEL, A.S., ZEITLINGER, M., SANDER, P. and NEMETH, J., 2017. Chloroquine enhances the antimycobacterial activity of isoniazid and pyrazinamide by reversing inflammation-induced macrophage efflux. International Journal of Antimicrobial Agents, vol. 50, no. 1, pp. 55-62. http://dx.doi.org/10.1016/j. ijantimicag.2017.02.022. PMid:28506804.

MOHAMMADI, A., KAZEMI, S., HOSSEINI, M., NAJAFZADEH VARZI, H., FEYZI, F., MORAKABATI, P. and MOGHADAMNIA, A.A., 2019. Chrysin effect in prevention of acetaminopheninduced hepatotoxicity in rat. Chemical Research in Toxicology, vol. 32, no. 11, pp. 2329-2337. http://dx.doi.org/10.1021/acs. chemrestox.9b00332. PMid:31625388.

MWAHEB, M., MOHAMMED, A., AL-GALAD, G., ABD-ELGAYD, A. and AL-HAMBOLY, H., 2017. Effect of nandrolone decanoate (anabolic steroid) on the liver and kidney of male albino rats and the role of antioxidant (antox-silymarin) as adjuvant therapy. Journal of Drug Metabolism Er Toxicology, vol. 8, no. 1, pp. 1-11. http://dx.doi.org/10.4172/2157-7609.1000224.

PHAM, M.D., HWANG, H., PARK, S.W., CUI, M., LEE, H. and CHUN, C., 2019. Leaf chlorosis, epinasty, carbohydrate contents and growth of tomato show different responses to the red/blue wavelength ratio under continuous light. Plant Physiology and Biochemistry, vol. 141, pp. 477-486. http://dx.doi.org/10.1016/j. plaphy.2019.06.004. PMid:31252253.

OSTAPOWICZ, G., FONTANA, R.J., SCHIØDT, F.V., LARSON, A., DAVERN, T.J., HAN, S.H., MCCASHLAND, T.M., SHAKIL, A.O., HAY, J.E., HYNAN, L., CRIPPIN, J.S., BLEI, A.T., SAMUEL, G., REISCH, J. and LEE, W.M., 2002. Results of a prospective study of acute liver failure at 17 tertiary care centers in the United States. Annals of Internal Medicine, vol. 137, no. 12, pp. 947-954. http:// dx.doi.org/10.7326/0003-4819-137-12-200212170-00007. PMid: 12484709 .

PIRI, A., SAHEBZADEH, N., ZIBAEE, A., SENDI, J.J., SHAMAKHI, L. and SHAHRIARI, M., 2020. Toxicity and physiological effects of ajwain (Carum copticum, Apiaceae) essential oil and its major constituents against Tuta absoluta (Meyrick) (Lepidoptera: 
gelechiidae). Chemosphere, vol. 256, pp. 127103. http://dx.doi. org/10.1016/j.chemosphere.2020.127103. PMid:32447114.

PITTOL, J.M.R., MILONA, A., MORRIS, I., WILLEMSEN, E.C., VAN DER VEEN, S.W., KALKHOVEN, E. and VAN MIL, S.W., 2020. FXR isoforms control different metabolic functions in liver cells via binding to specific DNA motifs. Gastroenterology, vol. 159, no. 5, pp. 1853-1865.e10. http://dx.doi.org/10.1053/j. gastro.2020.07.036. PMid:32712104.

RAMACHANDRAN, A., VISSCHERS, R.G., DUAN, L., AKAKPO, J.Y. and JAESCHKE, H., 2018. Mitochondrial dysfunction as a mechanism of drug-induced hepatotoxicity: current understanding and future perspectives. Journal of Clinical and Translational Research, vol. 4, no. 1, pp. 75-100. PMid:30873497.

ROCHE, M., RONDEAU, P., SINGH, N.R., TARNUS, E. and BOURDON, E.J.F., 2008. The antioxidant properties of serum albumin. FEBS Letters, vol. 582, no. 13, pp. 1783-1787. http://dx.doi.org/10.1016/j. febslet.2008.04.057. PMid:18474236.

SHARMA, R., GOYAL, N., SINGLA, M. and SHARMA, V.L., 2019. Berberis aristata ameliorates testicular toxicity induced by combination of first-line tuberculosis drugs (rifampicin+ isoniazid+ pyrazinamide) in normal Wistar rats. Journal of Dietary Supplements, vol. 16, no. 4, pp. 417-430. http://dx.doi. org/10.1080/19390211.2018.1470127. PMid:29953299.

SHENG, R., CHENG, W., LI, H., ALI, S., AGYEKUM, A.A. and CHEN, Q., 2019. Model development for soluble solids and lycopene contents of cherry tomato at different temperatures using near-infrared spectroscopy. Postharvest Biology and Technology, vol. 156, pp. 110952. http://dx.doi.org/10.1016/j. postharvbio.2019.110952.

TAN, W., ZHANG, L., DOERY, J.C.G. and SHEN, W., 2020. Study of paper-based assaying system for diagnosis of total serum bilirubin by colorimetric diazotization method. Sensors and Actuators. B, Chemical, vol. 305, pp. 127448. http://dx.doi. org/10.1016/j.snb.2019.127448.

TOSTMANN, A., BOEREE, M.J., AARNOUTSE, R.E., LANGE, W.C., VAN DER VEN, A.J. and DEKHUIJZEN, R., 2008. Antituberculosis drug-induced hepatotoxicity: concise up-to-date review. Journal of Gastroenterology and Hepatology, vol. 23, no. 2, pp. 192-202. http://dx.doi.org/10.1111/j.1440-1746.2007.05207.x. PMid:17995946.

TROUSIL, J., FILIPPOV, S.K., HRUBÝ, M., MAZEL, T., SYROVÁ, Z., CMARKO, D., SVIDENSKÁ, S., MATĚJKOVÁ, J., KOVÁČIK, L., PORSCH, B., KONEFAŁ, R., LUND, R., NYSTRÖM, B., RAŠKA, I. and ŠTĚPÁNEK, P., 2017. System with embedded drug release and nanoparticle degradation sensor showing efficient rifampicin delivery into macrophages. Nanomedicine; Nanotechnology, Biology, and Medicine, vol. 13, no. 1, pp. 307-315. http://dx.doi. org/10.1016/j.nano.2016.08.031. PMid:27613399.

UCHENDU, I.K., AGU, C.E. and ORJI, O.C., 2018. The effects of tomato (Lycopersicon esculentum) extract on carbimazole-induced biochemical alter-ations in pancreas of albino rats. Journal of Medical and Allied Sciences, vol. 8, no. 2, pp. 59-65. http:// dx.doi.org/10.5455/jmas.285861.

WANG, Y., CHAO, X., AHMAD, F.D., SHI, H., MEHBOOB, H. and HASSAN, W., 2019. Phoenix dactylifera protects against doxorubicin-induced cardiotoxicity and nephrotoxicity. Cardiology Research and Practice, vol. 2019, pp. 7395239. http:// dx.doi.org/10.1155/2019/7395239. PMid:31929900.

WANG, X., YONG, H., GAO, L., LI, L., JIN, M. and LIU, J., 2019a. Preparation and characterization of antioxidant and $\mathrm{pH}-$ sensitive films based on chitosan and black soybean seed coat extract. Food Hydrocolloids, vol. 89, pp. 56-66. http://dx.doi. org/10.1016/j.foodhyd.2018.10.019.

WANG, Y., XIANG, X., HUANG, W.-W., SANDFORD, A.J., WU, S.-Q., ZHANG, M.-M., WANG, M.G., CHEN, G. and HE, J.Q., 2019b. Association of PXR and CAR polymorphisms and antituberculosis drug-induced hepatotoxicity. Scientific Reports, vol. 9, no. 1, pp. 2217. http://dx.doi.org/10.1038/s41598-018-38452-z. PMid:30778091.

WEREMFO, A., ASAMOAH, K. and ABASSAH-OPPONG, S., 2011. Preliminary study on hepatoprotective activity of tomato (Solanum lycopersicum L.) pulp against hepatic damage in rats. Advances in Biological Research, vol. 5, no. 5, pp. 248-250. 